\title{
SIMPTOMATOLOGIA ALERGIEI LA PROTEINELE LAPTELUI DE VACĂ ÎN POPULAȚIA PEDIATRICĂ - STUDIU RETROSPECTIV
}

\author{
Netta Katry ${ }^{1}$, Anca Lădaru', Diana Goran ${ }^{1}$, Alexandra Ana-Maria Zotta ${ }^{1}$, \\ Ioana-Alina Anca ${ }^{1,2}$ \\ ${ }^{1}$ Universitatea de Medicină şi Farmacie ,, Carol Davila“, Bucureşti \\ 2Institutul pentru Ocrotirea Mamei şi Copilului „,Alfred Rusescu“, Bucureşti
}

\begin{abstract}
REZUMAT
Introducere. Metaanalize recente bazate pe studii populaționale relevă o heterogenitate considerabilă în prevalența reacțiilor alergice suspicionate şi confirmate, precum şi în sensibilizarea la ingestia de lapte de vacă. Reacțiile adverse apărute la consumul laptelui de vacă au şabloane diferite de prevalență în funcție de grupa de vârstă interesată. Există un interes public în creştere în ceea ce priveşte adevărata prevalență şi posibilitatea unei creşteri a apariției alergiilor alimentare în timp, cu precădere în rândul părinților şi al persoanelor implicate în îngrijirea şi educarea copiilor, precum şi în rândul personalului medical şi al producătorilor de alimente. Materiale şi metodă. Am derulat un studiu retrospectiv pe un lot de copii internați în Clinica de pediatrie a IOMC „Alfred Rusescu“ Bucureşti în perioada cuprinsă între ianuarie 2011 şi mai 2013. Obiectivul principal al studiului a fost de a analiza şi compara reacțiile alergice alimentare la copiii internați în Clinica de Pediatrie IOMC cu rezultatele găsite de alte grupuri de cercetare.

Rezultate. Din 312 pacienți evaluați prin panelul alimentar pediatric la 20 de alergeni, 64 au fost lgE pozitivi pentru proteinele laptelui de vacă.

Discuții. Am stabilit că simptomele associate reacțiilor adverse la lapte sunt frecvente în rândul sugarilor şi apar indiferent de vârsta gestațională la naştere sau de genul copilului. Aşa cum era de aşteptat am descoperit că cei mai mulți dintre copiii diagnosticați cu APLV proveneau din mediul urban. Simptomele debutează adesea în timpul primului an de viață, chiar şi la copiii alimentați exclusiv natural. Semnele şi simptomele importante de alarmă în cadrul APLV observate au fost falimentul creşterii, anemia carențială, precum şi simptomatologia digestivă şi respiratorie.
\end{abstract}

Cuvinte cheie: alergia la proteinele laptelui de vacă, falimentul creşterii

\section{INTRODUCERE}

Alergia la laptele de vacă este una dintre cele mai frecvente alergii alimentare la copii şi reprezintă un răspuns anormal al sistemului imun la lapte şi produsele care conțin lapte. Cel mai frecvent incriminat este laptele de vacă însă şi laptele de oaie, capră sau alte mamifere poate cauza o reacție similară. Prevalența estimată a alergiei la laptele de vacă (APLV) variază între 0,25\% şi 4,9\%, fiind mai mare la copii decât la adulți. În schimb suspiciunea de APLV este mult mai frecventă decât APLV confirmată. Semnele clinice ale APLV apar cel mai frecvent în primele luni după naştere, adeseori la câteva zile sau săptămâni după introducerea în dietă a laptelui de vacă. Semnele clinice pot să apară chiar şi la copiii alimentați exclusiv natural dar a căror mamă are în dietă lapte de vacă sau derivate ale acestuia. Pacienții cu APLV dezvoltă simptome gastrointestinale între 32 şi $60 \%$ dintre cazuri, simptome cutanate între 5 şi $90 \%$ dintre cazuri şi anafilaxie între 0,8 şi $9 \%$ dintre cazuri. Anafilaxia este una dintre cele mai mari probleme ale APLV, lucru sugerat de mai multe publicații.

Mecanismul imunologic al APLV este o reacție adversă asociată cu legarea IgE de antigene capabile să elaboreze un răspuns imun (1). Atunci când alergia nu este $\operatorname{IgE}$ mediată, alte clase de 
imunoglobuline, complexe imune sau răspunsuri celulare imune au fost identificate ca fiind responsabile de apariția semnelor şi simptomelor.

Diagnosticul este susținut pe baza examenului clinic, luând în considerare semnele şi simptomele caracteristice, însă suspiciunea de APLV trebuie confirmată sau exclusă prin eliminarea alergenului din dieta urmată de proba de încărcare la acesta. APLV este de obicei pasageră, până la vârsta de 3 ani $85 \%$ dintre copii recăpătându-şi toleranța la laptele de vacă (2).

\section{MATERIALE ŞI METODE}

Obiectivul principal al studiului a fost de a analiza şi compara reacțiile alergice alimentare la copiii internați în Clinica de Pediatrie IOMC cu rezultatele găsite de alte grupuri de cercetare. Obiectivele secundare au fost acelea de a evalua implicaţia posibilă a factorilor determinanți pentru APLVantecedente heredo-colaterale, vârsta diversificării cu alimente solide, greutatea la naştere (percentile), infecții, factori psiho-sociali şi de mediu. Astfel, a fost realizat un studiu retrospectiv al copiilor internaţi în Clinica de Pediatrie IOMC „Alfred Rusescu“, Bucureşti. Datele au fost obținute din foile de observție ale pacienților iar baza de date a inclus următoarele informații ale fiecărui pacient:

- Date demografice: Nume, vârsta la internare, gen, zona de rezidență.

- Antecedente personale: Vârsta gestaţională la naştere, tipul naşterii, greutatea la naştere.

- Istoricul alimentar: tipul şi durata alimentaţiei la sân, alimentarea artificială, diversificarea, tipul de alimentaţie la internare.

- Semne şi simptome la internare: durata şi prezentarea simptomelor, simptome asociate, acestea fiind împărțite în baza de date după sistemele implicate-cutanate, digestive şi respiratorii. Înălţimea şi greutatea. Istoric de faliment al creşterii, BRGE (boala de reflux gastroesofagian) sau leziuni cutanate.

- Rezultate de laborator: Nivelul seric IgE, nivelul hemoglobinei, al hematocritului, numărul de eozinofile în periferie, cholesterol total, proteine totale, sideremia, IgE specifice împotriva fractiilor laptelui de vacă - Lactalbumina 76, Lactoglobulina 77, Cazeina.

Toate datele au fost sumarizate într-o bază de date EXCEL.

Criteriile de includere au fost reprezentate de existenţa fişei de internare continuă în IOMC (Institutul pentru Ocrotirea Mamei şi Copilului) Alfred Rusescu în perioada ianuarie 2011 - martie $2013 \mathrm{cu}$ un panel pozitiv de alergeni la cel puțin 2 din cei 3 IgE specifice laptelui de vacă (Lactoglobulina 76, Lactoglobulina 77, Cazeina)

Criterii de excludere au fost reprezentate de prezenta unui panel negativ, pacienți la care nu existau date despre antecendente (copii abandonaţi) şi pacienți care nu au fost spitalizați în regim de spitalizare continuă.

\section{REZULTATE}

Din 312 pacienți evaluați prin panelul alimentar pediatric la 20 de alergeni, 64 au fost IgE pozitivi pentru proteinele laptelui de vacă. După ce datele au fost introduse în baza de date, acestea au fost interpretate comparativ retrospectiv, rezultatele fiind integrate într-o manieră logică.

Datele demografice sunt sumarizate în Tabelul 1.

TABELUL 1. Datele demografice şi clinice ale pacienților incluşi în studiu

\begin{tabular}{|l|l|c|}
\hline Pacienți & N = 64 (100\%) \\
\hline \multirow{3}{*}{$\begin{array}{l}\text { Date } \\
\text { demografice }\end{array}$} & Băieți & $33(51 \%)$ \\
\cline { 2 - 3 } & Naştere prin cezariană & $29(45,31 \%)$ \\
\cline { 2 - 3 } & Proveniență urbană & $50(79,13 \%)$ \\
\cline { 2 - 3 } & Vârsta la internare* (luni) & $21,5(5-138)$ \\
\hline \multirow{4}{*}{ Simptome } & Respiratorii & $15(23,44 \%)$ \\
\cline { 2 - 3 } & Gastrointestinale & $40(62,5 \%)$ \\
\cline { 2 - 3 } & Dermatologice & $20(40 \%)$ \\
\cline { 2 - 3 } & Falimentul creşterii & $39(60,94 \%)$ \\
\hline Istoric familial & Atopie & $11(17 \%)$ \\
\cline { 2 - 3 } & Alergie & $4(6 \%)$ \\
\hline Date paraclinice & Anemie** & $17(26,5 \%)$ \\
\hline
\end{tabular}

*Prezentat ca mediana (min-max)

**Conform criteriilor standard CDC pentru pacienții pediatrici (nivel scăzut al hemoglobinei)

Cei mai mulți pacienți $(62,5 \%)$ au prezentat simptome digestive (Tabelul 1). 35,85\% au avut diaree, $20,75 \%$ au avut scaune semiconsistente şi $5,56 \%$ au avut scaune cu mucus. $11,32 \%$ dintre pacienți au prezentat anorexie, iar $3,77 \%$ au refuzat alimentaţia cu produse lactate. 5,66\% dintre pacienți aveau constipație, iar 3,77\% au avut dureri abdominale. 5,66\% au prezentat vărsături. Scaune cu striuri sangvinolente sau cu alimente nedigerate au fost prezente la câte un pacient inclus $(1,89 \%)$.

$23,4 \%$ dintre pacienți au prezentat simptome respiratorii. 10,94\%, 7 pacienţi au prezentat wheezing iar restul au avut bronşiolită (4,69\%), IACRS $(3,13 \%)$, rinoadenoidita acută, traheomalacia şi sindromul bronhoobstructiv fiind prezente fiecare la câte un pacient (1,56\% fiecare). Cel mai frecvent simptom cutanat a fost erupția urticariană, prezentă 
la 12 pacienți (40\%). Dermatita atopică a fost prezentă la 5 pacienți $(16,67 \%)$ iar pruritul a fost prezent la 3 pacienți $(10 \%)$. Edemul, erupțiile maculopapuloase şi dermatita seboreică au fost prezente fiecare la $6,67 \%$ dintre pacienți, iar carotenemia, dermatita de scutec şi hemagiomatoza infantilă la 3,33\% dintre pacienți. 39 de pacienți $(60,94 \%)$ au prezentat falimentul creşterii la internare. La 53,1\% (34 de pacienti), simptomele au debutat înaintea împlinirii vârstei de un an. 23 de pacienți $(35,9 \%)$ aveau simptome încă dinaintea împlinirii vârstei de 6 luni. $\mathrm{Nu}$ au fost informaţii pentru 20,3\% dintre pacienți. Mediana vârstei pentru debutul simptomelor a fost de 9 luni (min. 0 luni, la naştere - max. 120 de luni), 4 pacienți $(6,25 \%)$ au avut simptome încă de la naştere, jumătate fiind alimentaţi natural şi cealaltă jumătate cu formula de lapte.

\section{ANTECEDENTE HEREDOCOLATERALE ŞI PERSONALE}

17\% dintre pacienţi au avut istoric de alergii şi atopie cu episoade de urticare şi multiple alergii la gluten, orez şi banană.

\section{ISTORIC FAMILIAL}

$6 \%$ dintre pacienți (4 pacienți) au avut antecedente familiale de alergii multiple şi simptome similare la cel puțin unul dintre părinți. $13 \%$ dintre pacienți ( 8 pacienți) nu au avut istoric familial relevant de alergii (HIV, rahitism, covulsii febrile), iar restul $(81 \%)$ nu au avut niciun istoric familial declarat de părinți.

\section{REZULTATE DE LABORATOR}

26,5\% $(n=17)$ dintre pacienți au avut anemie la internare (definind anemia conform criteriilor standard CDC pentru pacienții pediatrici).

\section{DISCUȚII}

Într-un studiu publicat de Johns Hopkins University School of Medicine în 2007, 807 pacienți cu APLV IgE mediată au fost incluşi în studio, raportul masculin:feminin fiind de 2:1 (3). Rezultatele obținute în cadrul studiului noastru diferă, cel mai probabil datorită eşantionului redus pe care 1-am inclus în baza de date.

Predispoziția genetică ar putea explica incidența crescută la pacienții de sex masculin datorită unui defect genetic X-linkat asociat cu o patologie alergică ce ar putea fi evidențiată mai degrabă la pacienții de sex masculin (cariotip XY), încă de la vârste mici. (4)

Studii diferite indică faptul că la copii născuți prin cezariană există un risc mai mare de dezvoltare a alergiilor alimentare, susținând ipoteza că factorii ce interferă cu colonizarea bacteriană ar putea juca un rol în dezvoltarea alergiilor alimentare (5).

Conform raportului OMS din 2010, 23,6\% dintre naşterile din România au fost prin operație cezariană. Acest aspect este important când evaluăm rezultatele prezentului studiu, având în vedere că proporția copiilor cu simptome alergice născuți prin cezariană este mare.

S-a observant că şi mediul de provenienţă poate influența apariția alergiilor alimentare (6). 38.465 de copii au fost evaluați într-un studiu cu privire la alergiile alimentare derulat în SUA în 2009. Prevalența alergiilor alimentare a fost direct proporțională cu creşterea densităţii populației de la $6,2 \%$ în mediul rural la 9,8\% în mediul urban. Diferența semnificativ statistic mai mare în favoarea mediului urban a rămas semnificativă şi după ce a fost ajustată după rasă/etnie, vârstă, latitudine sau venitul pe cap de locuitor.

Teoria igienei sugerează că îmbunătățirea standardelor de viață şi scăderea expunerii la factorii infecțioşi ar putea facilita dezvoltarea sensibilității. Şi alţi factori existenți în mediul urban cum ar fi expunerea la particule provenite din arderile motoarelor diesel, tratamentul cu antibiotice sau chiar cel cu suplimente pe bază de progesteron administrat mamei par să influențeze apariția alergiilor alimentare.

Expunerea la animale de companie este destul de frecventă atât în mediul urban, cât şi în mediul rural. Această expunere a avut fie rol protector fie a fost identificată ca fiind factor de risc pentru apariţia alergiilor alimentare. Totuşi, niciunul dintre aceşti factori nu oferă o explicație definitivă pentru diferențele observate dintre mediul urban şi mediul rural (7).

Conform mai multor studii, cele mai frecvente simptome respiratorii la copiii cu APLV sunt reprezentate de rinoree, wheezing, tuse cronică a sugarului şi nou-născutului (nelegată de vreun agent infecțios) şi stridor, wheezing şi dispnee ca simptome alergice imediate. Rezultatele acestui studiu relevă acelaşi lucru - wheezingul; deşi în nicio fişă nu a fost trecută tusea cronică, aceasta ar putea fi de fapt mascată sub prezența consemnării episoadelor recurente de bronşiolită.

Cele mai frecvente simptome gastrointestinale descrise în literatura de specialitate au fost disfagia, regurgitaţia, durerile abdominale, vărsăturile, anorexia, refuzul alimentației, diareea şi/sau pierderea 
intestinală de proteine sau de sânge, constipația cu sau fără rash perianal. Simptomele găsite la lotul nostru de pacienți coincid în cea mai mare măsură cu simptomele prezentate anterior, deşi niciun pacient nu a prezentat disfagie sau rash perianal.

Numai $6,15 \%$ dintre pacienți au asociat BRGE la internare, deşi conform DRACMA (8) aproximativ $40 \%$ dintre copiii trimişi la specialist pentru tratamentul BRGE se dovedesc a avea APLV ulterior. Aceas lucru se întâmplă probabil datorită faptului că la examinarea iniţială anumite aspecte sunt neglijate şi care ar ține de simptomele respiratorii sau de interpretarea greşită a simptomelor asociate BRGE.

Simptomele frecvente ale BRGE cum ar fi vărsăturile, tusea şi wheezingul persistent, balonarea, refuzul alimentației sau dificultăți ale deglutiției, toate sunt corelate cu APLV şi pot orienta eronat medicul către BRGE. Urticaria nelegată de infecții, medicamente sau alte cauze, eczema atopică sau angioedemul sunt menționate în multe studii ca fiind simptome prevalente la pacienții cu APLV. Datele obținute în acest studiu confirmă datele din literatura de specialitate cu excepția angioedemului, în acest studiu nefiind identificat niciun pacient care să asocieze acest diagnostic.

Conform Ghidului de diagnostic şi tratament al pacientului cu alergie la proteinele laptelui de vacă, mulți copii cu APLV prezintă afectarea a cel puțin două din următoarele sisteme digestiv (50-60\%), cutanat (50-60\%), respirator (20-30\%). Prevalențele acestea nu au fost similare cu cele găsite la pacienții incluşi în studiul de faţă, probabil datorită lotului restrâns de pacienți, iar prin recrutarea unui număr mai mare, procentele putând probabil să se apropie de cele prezentate în metaanalize.

Din datele obținute, 60,94\% (39 de pacienți) au avut falimentul creşterii obiectivat la momentul internării. Distribuția greutății pacienților nu a fost gaussiană (distribuție non-normală), deşi din datele obținute de la părinți, distribuția greutății la naştere a pacienţilor incluşi în studiu a fost gaussiană (pacienții au fost puşi pe percentile). Aceste date se corelează cu cele din literatura de specialitate care sugerează că majoritatea copiilor cu APLV vor avea un ritm de creştere ulterioară mai lent (9).

Mai multe studii au demonstrat că la copiii ce prezintă un risc mai mare de a dezvolta boli alergice, alimentarea naturală în primele 4 luni scade riscul incidenței dermatiei atopice şi a APLV (10).

În prezentul studiu se observă ca rezultatele au fost diferite, $70 \%$ dintre copiii alimentaţi natural au avut simptome mai devreme de vârsta de 2 ani. Aceasta datorită probabil faptului că aceşti copii nu au fost alimentați exclusiv natural primele 4 luni. Mediana perioadei de alăptare a fost de 1,75 luni pentru toată populaţia studiului şi de 3 luni în grupul celor cu simptome precoce ale APLV.

Multe studii (1) asociază APLV cu alergii alimentare diverse (ou, alune sau alimente ce conțin aceste ingrediente). În prezentul studiu, majoritatea copiilor nu au avut şi alte alergii asociate, probabil datorită faptului ca APLV este prima alergie care este descoperită şi care creşte adresabilitatea la medicul pediatru (1).

Istoricul de astm alergic, rinită, eczema, simptome respiratorii precoce cu simptome cutanate sau gastrointestinale sunt consideraţi factori de risc pentru APLV persistentă.

Agregările familiale de alergii respiratorii sau alimentare sugerează şi un mecanism genetic însă locusurile specifice ale APLV rămân încă „Terra Incognita“". Genotipurile nu sunt încă bine cunoscute, iar susceptibilitatea genetică şi distribuţia acesteia în rândul populației sunt necunoscute.

\section{REZULTATE DE LABORATOR}

Conform OMS, anemia în rândul populației pediatrice se ridică la $39,8 \%$, fiind considerate o problemă moderată de sănătate publică.

Anemia feriprivă este o problemă serioasă de sănătate publică în țările aflate în curs de dezvoltare. Laptele de mamă oferă cantităţi adecvate de fier pentru primele 6 luni. După această perioadă, o dietă ce necesită adăugarea fierului este esențială pentru buna dezvoltare. Laptele de vacă are cantități şi biodisponibilități reduse de fier, cu un exces de minerale (mai ales calciu) şi proteine, ce interferă astfel $\mathrm{cu}$ absorția fierului din alimente. Laptele de vacă este asociat şi cu mici hemoragii intestinale la copilul mic. Utilizarea laptelui de vacă în locul altor alimente cu o biodisponibilitate superioară a fierului s-a dovedit a fi un factor de risc pentru anemie (9).

Limitările studiului: din cauza numărului mic de pacienți cu APLV diagnosticată, rezultatele nu se pot extrapola către populația generală, întrucât acesta nu poate fi considerat un eşantion reprezentativ. Totuşi rezultatele obținute pe acest lot mai mic au fost comparate şi comparabile cu cele recente ale altor metaanalize.

\section{CONCLUZII}

În acest studiu a fost demonstrat că simptomele asociate APLV sunt frecvente la copii şi apar indiferent de vârsta gestaţională sau genul pacientului. 
S-a observat că mai mulți copii cu APLV au provenit din mediul urban decât din cel rural.

Simptomele au apărut mai ales în primul an de viaţă, chiar şi la copii alimentaţi exclusiv natural.

Falimentul creşterii este o problemă importantă deoarece majoritatea copiilor cu APLV asociază şi falimentul creşterii.

Diagnosticul de APLV ar trebui căutat la copiii cu simptome digestive, cutanate şi respiratorii.

Deşi conform ghidurilor OMS, diversificarea nu ar trebui realizată mai devreme de 4 luni şi nu mai târziu de vârsta de 6 luni şi nu există consens în ceea ce priveşte relevanța întârzierii introducerii diversificării mai târziu de această perioadă pentru a obține un efect protector împotriva dezvoltării APLV, în studiul nostru am găsit o diferență mică de 4 luni în ceea ce priveşte vârsta de debut a acestei patologii la copiii expuşi precoce la alimentaţia solidă, informație ce trebuie explorată sau aprofundată prin studii ulterioare.

Istoricul familial al altor alergii joacă un rol important în predicția riscului copilului de a dezvolta APLV şi nu ar trebui să fie subestimat de către medicul de familie.
O altă problemă importantă la copiii cu APLV este asocierea anemiei carențiale, prezentă chiar şi la populația non-alergică. Ea pare să aibă totuşi o prevalență mai mare la grupul de copii cu APLV.

Este cunoscut faptul că aproximativ jumătate dintre copiii care au dezvoltat reacții adverse la laptele de vacă în primele luni de la administrare nu vor păstra aceste manifestări după vârsta de un an. Copiii care vor menține APLV după această vârstă îşi vor păstra simptomele sau vor dobândi altele noi.

Din păcate urmărirea pacientului este dificil de realizat şi aceasta poate duce la subestimarea prevalenței reale a APLV. Studii viitoare ar fi utile pentru evaluarea prevalenței APLV în cadrul populaţiei pediatrice.

Din considerente economice, sociale şi practice este important ca în România să se stabilească un protocol care să includă un set de teste şi examinări pentru copii care par să aibă probleme nutriționale. 